Article

\title{
Characterization and antimicrobial efficacy of bovine dermcidin, a novel antimicrobial peptide gene
}

\author{
Nevien M. Sabry ${ }^{1}$ and Tarek A. A. Moussa ${ }^{2 *}$ \\ 1 Cell Biology Department, Genetic Engineering and Biotechnology Division, National Research Centre, Giza \\ 12622, Egypt; neviensabry@yahoo.com \\ 2 Botany and Microbiology Department, Faculty of Science, Cairo University, Giza 12613, Egypt.; \\ tarekmoussa@yahoo.com \\ * Correspondence: tarekmoussa@yahoo.com; Tel.: +20-1001-531-738
}

Abstract: Description of a novel bovine antimicrobial peptide and its antimicrobial spectrum. RNA isolation and RT-PCR were done from various tissues. DCD peptide was synthesized, and antimicrobial activity was analyzed. Bovine dermcidin gene contains five exons intermittent by 4 introns. Bovine DCD-mRNA was 398 bp with ORF 336 bp. Bovine DCD was expressed in skin and blood. Analysis of the amino acid compositions revealed that cysteine was repeated 6 times indicating the presence of 3 disulfide bonds that play role in the peptide stability. Staphylococcus epidermidis, Streptococcus bovis, and Enterococcus faecalis were affected by Bovine DCD peptide. Highest antimicrobial effect was at 50 and $100 \mu \mathrm{g} / \mathrm{ml}$. The effect on Escherichia coli and Candida albicans was slightly low. In all bacteria, Bovine DCD peptide activity did not affect by varying $\mathrm{pH}$ values, but in Staphylococcus aureus, the activity was affected greatly at $\mathrm{pH} 4.5$ and 5.5. The optimum salt concentrations were 100 and $50 \mathrm{mM} \mathrm{NaCl}$ with all bacterial strains and E. coli, respectively. In case of $C$. albicans, the antimicrobial activity of Bovine DCD peptide decreased with increasing the $\mathrm{pH}$ value regardless the $\mathrm{NaCl}$ concentration. The $\mathrm{pH} 6.5$ of the sweat buffer was the optimum for the Bovine DCD peptide activity.

Keywords: Bos taurus; skin; bovine dermcidin; RT-PCR; antimicrobial activity

\section{Introduction}

The antimicrobial peptides (host-defense peptides) are important molecules of innate immune defense with diverse species protecting epithelial barriers. Many antimicrobial peptides show a wide antimicrobial spectrum against many pathogens including viruses, bacteria, and fungi [1]; they also act as anti-cancer and aid in wound healing [2]. The antimicrobial peptides have been found in all organisms from bacteria to humans. These antimicrobial peptides have been conserved through evolution across different species with many characteristics of separate AMPs classes. Because of their small size and their high potency, they have been favored through evolution $[3,4]$. The induction pathways for these peptides in vertebrates, insects, and plants are highly conserved $[5,6]$. In animals, AMPs are produced at sites that are in contact with microbes, like skin cells or mucosal epithelial cells (oral, respiratory, gastrointestinal, genitourinary, etc.). AMPs in the animal can be constitutively secreted or in response to infection [7].

Ruminant animals (e.g. cattle, sheep, goats, etc.) have a huge number of AMPs that serve as natural innate barriers limiting microbial infectious diseases and proceed as a vital component in reaction to microbial infectious diseases $[8,9]$. These peptides fluctuate in mechanisms of activity and 
size. There are two groups of AMPs: 1) anionic AMPs, which are a small group present in ruminants, rich in aspartic and glutamic acids, their general antimicrobial activity Gram-negative, Gram-positive bacteria [10] and 2) larger group of cationic AMPs originate in all domestic animals.

There are over 1500 different antimicrobial peptides have been described [11-14] and are being evaluated as possible alternatives to conventional antibiotics. Also, the amphoteric characters of many AMPs enhance their permeation into the lipid of cell membrane causing its destruction and then cell death $[15,16]$.

Notably and anomalous for AMPs, the antimicrobial spectrum of DCD-1L is preserved over a broad $\mathrm{pH}$ range even at high salt concentrations, which similar the conditions of human sweat [17]. This notable activity proposed that the functional mechanism of DCD-1L might be different from most other AMPs. There are studies showed a binding of DCD-1L to the bacterial surface and an interaction with bacterial membrane phospholipids [18,19].

In this study, we will describe a novel bovine antimicrobial peptide secrete by skin cells and the spectrum of antimicrobial activity against Gram-positive and negative bacteria as well as fungi.

\section{Materials and Methods}

\subsection{Collection of samples}

Different tissues from Bos taurus were collected that included skin, spleen, liver, muscle, intestine, kidney and blood. All tissue samples were collected using Allflex Tissue Sampling Units (TSU). Freeze all samples in liquid nitrogen immediately in the field and transfer to $-80^{\circ} \mathrm{C}$ freezer once back in the lab till used.

\subsection{RNA expression analysis of dermcidin}

RT-PCR was done from various tissues. Isolation of RNA was done using TriFast ${ }^{\mathrm{TM}}$ (Peqlab, Erlangen, Germany) in addition; PCR was performed using cDNA from many bovine tissues. The mixture contained $5 \mu$ of the template, $1 X$ Taq buffer, $0.4 \mathrm{mM}$ dNTPs, $0.4 \mu \mathrm{M}$ of each primer and 0.5 $\mu \mathrm{l}$ of Taq-polymerase (Fermentas, Germany). The used primers were 5'-GACACACTAGAGACCAGAATCTCC-3' and 5'-TCAAAACATCTGTCCTCCCAC-3', producing a product with $\sim 400 \mathrm{bp}$. The PCR conditions were 35 cycles at $95^{\circ} \mathrm{C}$ for $1 \mathrm{~min}, 58^{\circ} \mathrm{C}$ for $1 \mathrm{~min}$ and $72^{\circ} \mathrm{C}$ for 80 s. The PCR reaction was repeated triple with two negative and one positive control. A ladder of 100-bp (Fermentas, Germany) was used in agarose gel electrophoresis.

\subsection{Antimicrobial assay}

Bovine DCD peptide was synthesized by FlexPeptide ${ }^{\mathrm{TM}}$ Technology (GenScript, USA). The antimicrobial activity of Bovine DCD was analyzed as described by Valore et al. [20] using Gram-positive bacteria included Enterococcus faecalis (ATCC29212), Staphylococcus epidermidis (ATCC1228), methicillin-resistant Staphylococcus aureus (MRSA) (ATCC43330), Streptococcus bovis (ATCC49147); while Gram-negative bacteria included Escherichia coli (ATCC25922), and the fungus Candida albicans (ATCC1021). E. coli was grown in LB medium, S. epidermidis in Nutrient medium, S. bovis in Trypticase soy medium with defibrinated sheep blood, E. faecalis and S. aureus in Columbia medium, and C. albicans in Casein hydrolysate medium. The bacterial and yeast concentrations were determined photometrically. Bacteria and yeast were diluted to a concentration of $2 \times 10^{6} \mathrm{CFU} / \mathrm{ml}$ in phosphate buffer. The cells were incubated at $37^{\circ} \mathrm{C}$ for $4 \mathrm{~h}$ with different peptide concentrations or sweat fractions in $200 \mu \mathrm{l}$ of phosphate buffer. The microbial cultures were diluted 1:50-500, and $50 \mu \mathrm{l}$ and $100 \mu \mathrm{l}$ of the solutions were plated on agar plates in duplicate. At least five plates from each 
experiment were evaluated and the mean number of colonies determined. The bactericidal activity of the tested reagents represented the percentage of cells that killed and was expressed as:

Bactericidal activity $=1-\frac{\text { number of cells survival after peptide incubation }}{\text { number of cell survival after control peptide incubation }} X 100$

To examine the activity profile of Bovine DCD and sweat fraction that contained Bovine $\mathrm{DCD}$, the microorganisms were incubated for $4 \mathrm{~h}$ with $10 \mu \mathrm{g} / \mathrm{ml}$ of Bovine DCD or sweat fraction under the following conditions: phosphate buffer $(10 \mathrm{mM})+$ either 25,100 or $150 \mathrm{mM}$ sodium chloride, phosphate buffer (10 mM) at pH 4.5, 5.5, 6.5 or 7.5; sweet buffer $(40 \mathrm{mM} \mathrm{NaCl}, 10 \mathrm{mM} \mathrm{KCl}$, $1 \mathrm{mM} \mathrm{CaCl}_{2}, 1 \mathrm{mM} \mathrm{MgCl}_{2}$ and $1 \mathrm{mM} \mathrm{Na}$-dihydrogen phosphate) at $\mathrm{pH} 5.5$ or 6.5. The antimicrobial activity was assessed as outlined above.

\section{Results}

The discovered bovine dermcidin gene was not published before, we detect the locus and the sequence of the gene using in silico determination based on conserved synteny between human chromosome 12, bovine chromosome 5, monkey chromosome 11 and chimpanzee chromosome 12 [21-23]. By alignment the human dermcidin gene in the cattle genome, we detect the sequence which was aligned in the cattle genome and by analysis the segment we find the sequence of bovine DCD gene (Table S1 and Figure S1).

\subsection{Analysis of bovine dermacidin nucleotid}

The gene was designated dermcidin (Bovine $D C D$ ) that had no homology to any bovine published gene sequence. Sequencing of the products identified a full-length Bovine DCD-cDNA of $398 \mathrm{bp}$ with an open reading frame of $336 \mathrm{bp}$ (Figure 1). The full length of dermcidin gene was 2205 bp, containing five exons intermittent by 4 introns varying in size, in which the exon 1 was 59 bp, exon 2 was 23 bp, exon 3 was 112 bp, exon 4 was 90 bp, exon 5 was 52 bp and finally 3 bp stop codon (Figure 1), when compared with the PCR fragment Bovine DCD-cDNA sequence. All the introns splice junctions corresponded to the GT-AG rule. The Genebank accession number for bovine $D C D$ gene sequence we identified is AB932628.

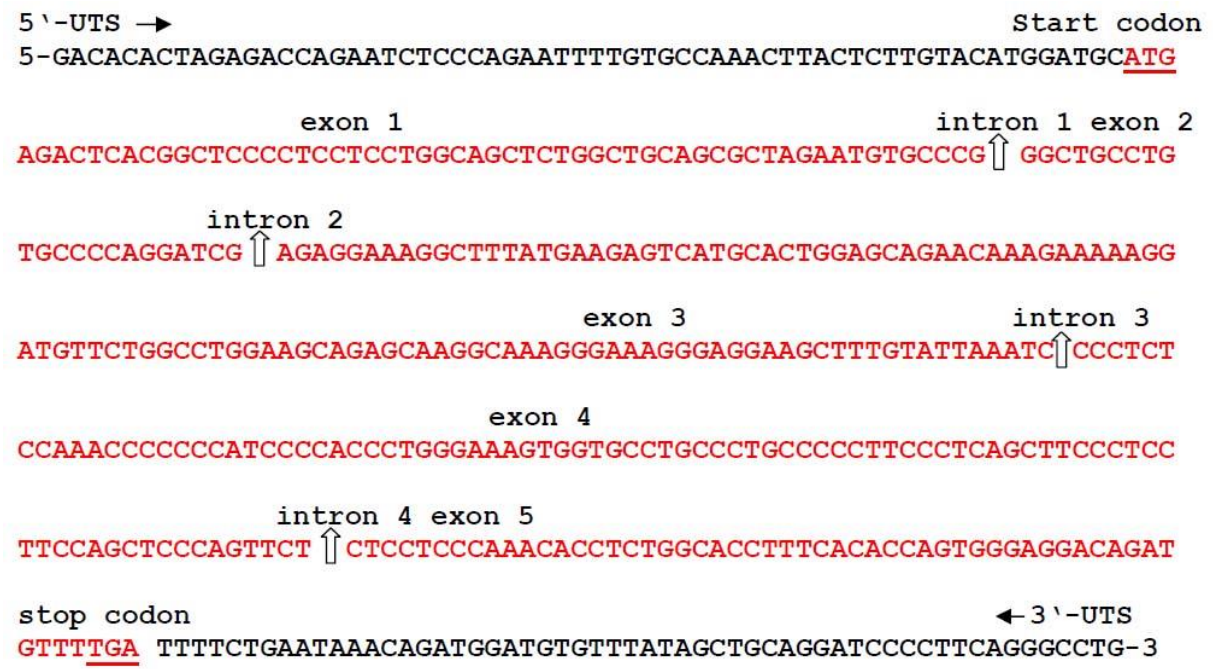

Figure 1. Structure of the bovine dermcidin gene (bovine $D C D$ ) secreted by skin of Bos taurus and has accession number AB932628. 


\subsection{Analysis of bovine dermacidin peptide}

To determine the expression profile of Bovine $D C D$, RNA from different bovine tissues were tested using reverse transcriptase-PCR (RT-PCR). Bovine DCD was expressed in bovine skin tissue and blood (Figure S2). However, expression was not detected in any other tissues (spleen, liver, muscle, intestine, and kidney). These results indicated that Bovine $D C D$ expression was restricted to cells in the bovine skin. By analyzing the amino acids sequence of the Bovine DCD peptide indicated that is composed of 18 different amino acids repeated to produce a peptide with 112 amino acids. The most abundant amino acids were proline and leucine (repeated by 15 times each) and the rarest amino acids were histidine, asparagine, and tryptophan (represented by one time each). Cysteine was repeated 6 times which indicated that there are 3 disulfide bonds that play a role in the stability of the peptide (Table 1). The peptide sequence was applied to SignalP-4.1 online program (http://www.cbs.dtu.dk/services/SignalP/) to determine the signal peptide length that was the first 21 amino acids (Figure 2). Also, the predicted Bovine DCD-peptide sequence was applied to Compute pI/Mw (http://web.expasy.org/cgi-bin/compute pi/pi tool) to determine the theoretical isoelectric point and molecular weight of the peptide that was 9.24 for $\mathrm{pI}$ and $11.91 \mathrm{kDa}$ for Mw.

Table 1: Amino acids composition of the deduced Bos tautrus DCD-AMP

\begin{tabular}{lccc}
\hline Amino acid & Single letter & Number & Type of amino acid \\
\hline Methionin & $\mathrm{M}$ & 3 & Non polar (hydrophobic) \\
Arginine & $\mathrm{R}$ & 5 & +ve \\
Leucine & $\mathrm{L}$ & 15 & Non polar (hydrophobic) \\
Threonine & $\mathrm{T}$ & 4 & Polar (hydrophilic) \\
Alanine & $\mathrm{A}$ & 12 & Non polar (hydrophobic) \\
Proline & $\mathrm{P}$ & 15 & Non polar (hydrophobic) \\
Glutamic acid & $\mathrm{E}$ & 7 & -ve \\
Cysteine & $\mathrm{C}$ & 6 & Polar (hydrophilic) \\
Glycine & $\mathrm{G}$ & 10 & Non polar (hydrophobic) \\
Isoleucine & $\mathrm{I}$ & 2 & Non polar (hydrophobic) \\
Lysine & $\mathrm{K}$ & 8 & +ve \\
Phenylalanine & $\mathrm{F}$ & 5 & Non polar (hydrophobic) \\
Serine & $\mathrm{S}$ & 8 & Polar (hydrophilic) \\
Histidine & $\mathrm{H}$ & 1 & +ve \\
Glutamine & $\mathrm{Q}$ & 7 & Polar (hydrophilic) \\
Asparagine & $\mathrm{N}$ & 1 & Polar (hydrophilic) \\
Tryptophan & $\mathrm{W}$ & 1 & Non polar (hydrophobic) \\
Valine & $\mathrm{V}$ & 2 & Non polar (hydrophobic) \\
\hline
\end{tabular}




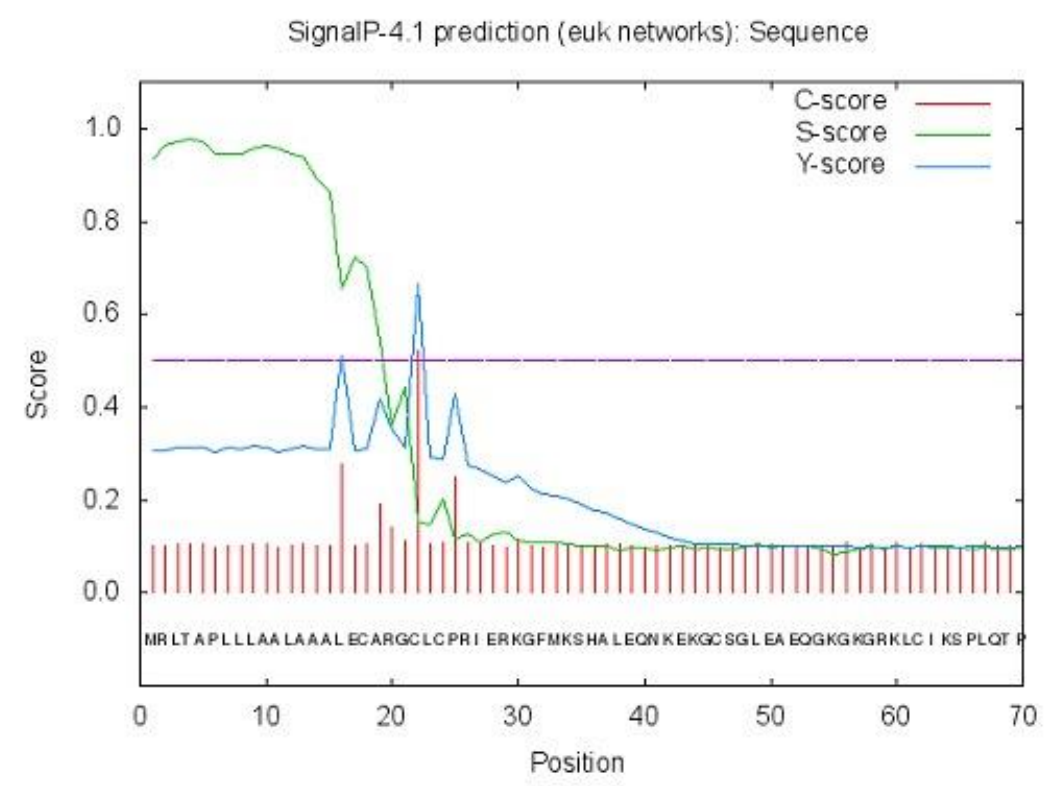

MRLTAPLLLAALAAALECARGCLCPRIERK GFMKSHALEQNK EK GCSGLEAEQGKGKGRKLCIK SP LQTPPSPPWESGACPAPFPQLPSFQLPVLSSQTPLAPFTPVGGQMF

Figure 2. The signal peptide length was determined using online SignalP-4.1 euk predictions (http://www.cbs.dtu.dk/services/SignalP/).

\subsection{Antimicrobial activity of bovine dermacidin peptide}

The synthesized Bovine DCD peptide had a broad antimicrobial activity against gram +ve, gram -ve bacteria and yeast fungus. For $\mathrm{G}+\mathrm{ve}$ bacteria, the most affected species were S. epidermidis, S. bovis and E. faecalis, respectively, which the antimicrobial effect was increased with peptide concentration increased. The highest antimicrobial effect was achieved at 50 and $100 \mu \mathrm{g} / \mathrm{ml}$, where no significant difference between the two concentrations in the effect. The methicillin-resistant $S$. aureus (MRSA) behaved the same behavior but the maximum antimicrobial effect was achieved at 50 $\mu \mathrm{g} / \mathrm{ml}$, and then decreased at $100 \mu \mathrm{g} / \mathrm{ml}$. For $\mathrm{G}$-ve bacterium (E. coli) the antimicrobial effect was slightly less than $G$ +ve bacteria. In case of $C$. albicans, it affected with the antimicrobial peptide, where no effect at $1 \mu \mathrm{g} / \mathrm{ml}$ and the inhibitory effects starts at $5 \mu \mathrm{g} / \mathrm{ml}$ increase reaching the maximum at $100 \mu \mathrm{g} / \mathrm{ml}$ (Figure 3).

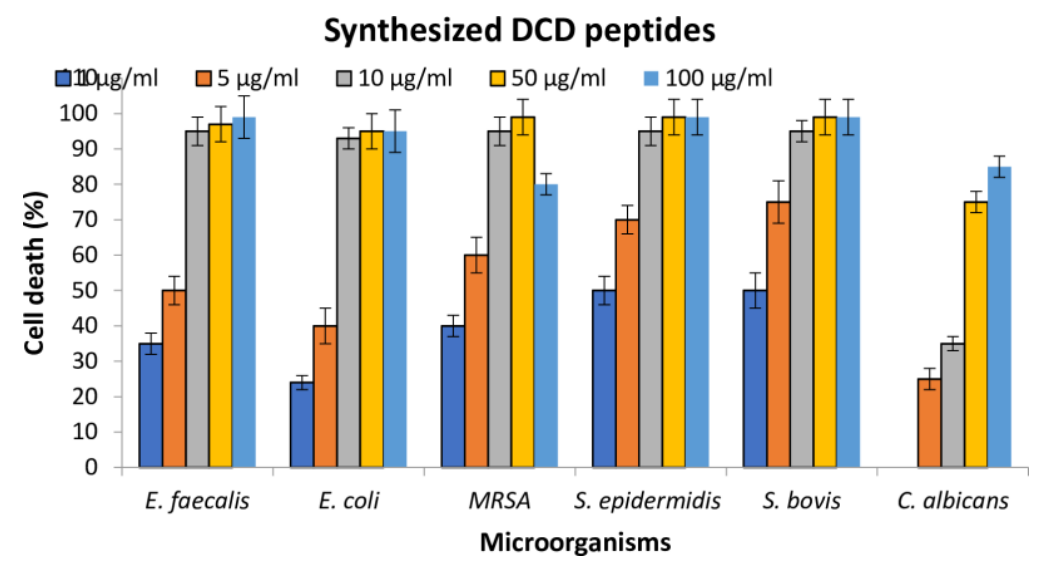

Figure 3. Antimicrobial efficacy (cell death) of various concentrations of synthesized Bovine DCD peptides against selected microorganisms. 
To study the antimicrobial efficacy of the Bovine DCD peptide, we study the antimicrobial activity using different $\mathrm{pH}$ values with or without $\mathrm{NaCl}$ concentrations. In all bacterial strains used the varying of $\mathrm{pH}$ value did not affect in the activity of Bovine DCD peptide, except in S. aureus the antibacterial activity affected greatly at $\mathrm{pH} 4.5$ and 5.5, where the cell death percent is less than $30 \%$ (Figure 4). In presence of $\mathrm{NaCl}$ concentrations, the antimicrobial activity of Bovine DCD peptide did not affect by varying the salt concentrations, where $100 \mathrm{mM} \mathrm{NaCl}$ was the optimum concentration which gave the highest antibacterial activity in all bacterial strains except $E$. coli in which the antibacterial activity was affected greatly after $50 \mathrm{mM} \mathrm{NaCl}$ concentration, where the optimum $\mathrm{NaCl}$ concentration was $50 \mathrm{mM} \mathrm{NaCl}$. The behavior of $C$. albicans was on contrary to the bacterial behavior, where the antimicrobial activity of Bovine DCD peptide decreased with increasing the $\mathrm{pH}$ in absence and presence of $\mathrm{NaCl}$ concentrations. In general $\mathrm{pH} 6.5$ of the sweat buffer was the most suitable for increasing the activity of the Bovine DCD peptide in all bacterial strains (Figure 4).

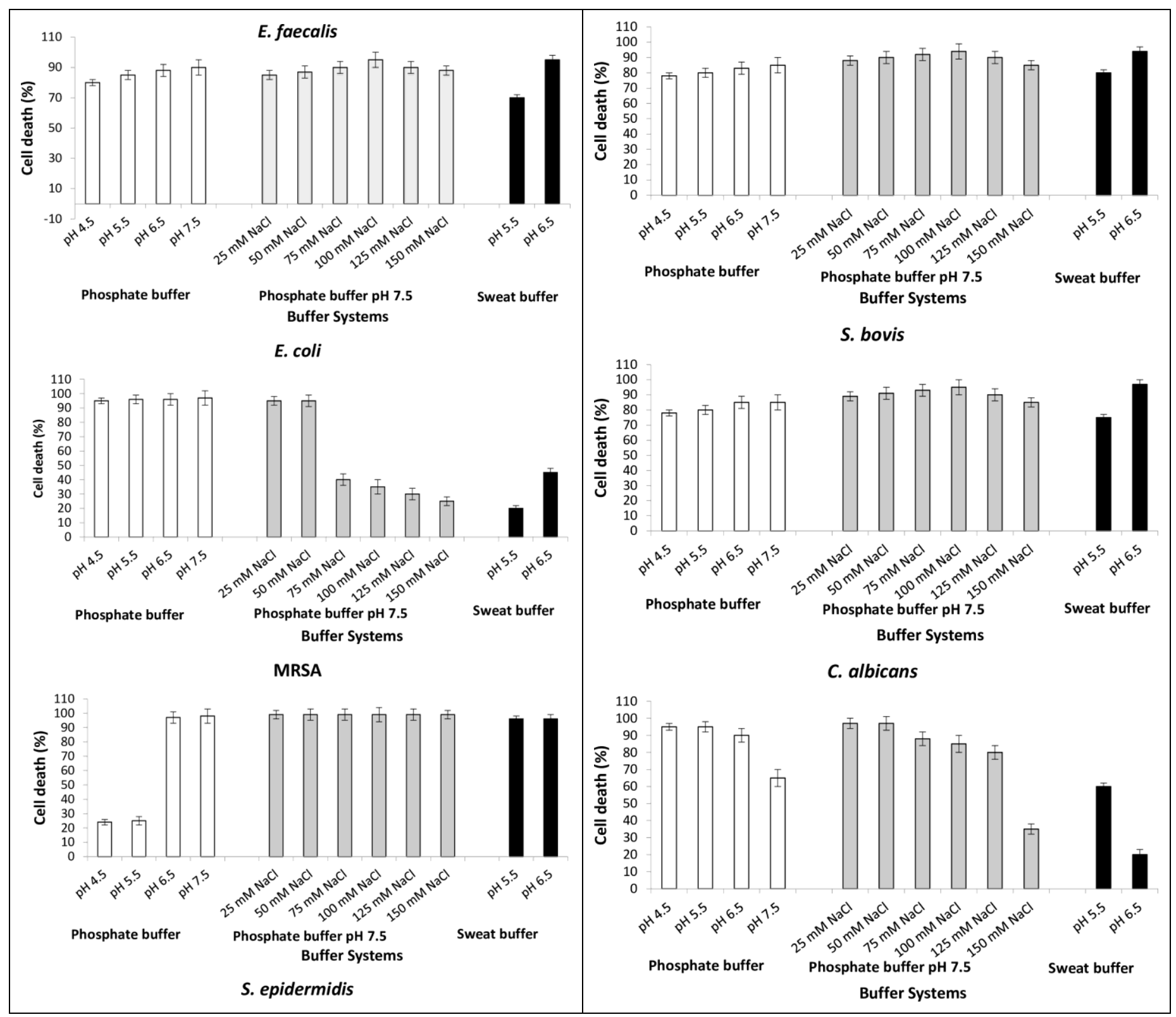


Figure 4. Antimicrobial efficacy of the bovine DCD secreted from skin cells of Bos taurus on selected microorganisms, using different $\mathrm{pH}$ values of phosphate buffer, $\mathrm{pH} 7$ of phosphate buffer amended with different concentrations of salt, and different $\mathrm{pH}$ values of sweat buffer.

\section{Discussion}

The discovery of antimicrobial peptides in animals is expanding and advances in this field are expected. It will be likely to find the new genes encoding antimicrobial peptides in sequenced animal genomes [24].

The full length of dermcidin gene was $2205 \mathrm{bp}$, containing five exons intermittent by 4 introns varying in size, in which the exon 1 was 59 bp, exon 2 was 23 bp, exon 3 was 112 bp, exon 4 was $90 \mathrm{bp}$, exon 5 was $52 \mathrm{bp}$ and finally $3 \mathrm{bp}$ stop codon, when compared with the PCR fragment Bovine $D C D$-cDNA sequence. Sequencing of the products identified a full-length Bovine $D C D$-cDNA of $398 \mathrm{bp}$ with an open reading frame of $336 \mathrm{bp}$

These findings agreed with Schittek et al. [17] who determined that the human DCD gene contains 5 exons and is expressed as a single transcript. Dermcidin was identified for the first time in human as a gene specifically expressed in sweat glands, coding for a 110-amino acid protein (Bovine DCD).

Bovine $D C D$ was expressed in bovine skin tissue and blood only. However, expression was not detected in any other tissues (spleen, liver, muscle, intestine, and kidney). These results indicated that Bovine $D C D$ expression was restricted to cells in the bovine skin. Bovine DCD peptide composed of 18 different amino acids repeated to produce a peptide with 112 amino acids. The most abundant amino acids were proline and leucine (repeated by 15 times each) and the rarest amino acids were histidine, asparagine, and tryptophan (represented by one time each). Cysteine was repeated 6 times which indicated that there are 3 disulfide bonds that play a role in the stability of the peptide. The signal peptide length was the first 21 amino acids. Also, the theoretical isoelectric point and molecular weight of the peptide that was 9.24 for $\mathrm{pI}$ and $11.91 \mathrm{kDa}$ for $\mathrm{Mw}$.

The product of full-length of the human dermcidin gene is 110 amino acids, with 19 amino acids as N-terminal signal peptide [25]. The 110 amino acids precursor is processed proteolytically in sweat, giving rise to many truncated DCD peptides differing in length and charge [26-28].

Eccrine are the most developed and abundant glands in humans. They are distributed in all over the body surface. On the other hand, in cow, donkey, horse, camel and canid species, apocrine glands are distributed on all over the surface of the animal body and have evaporative cooling functions. Eccrine glands secret sweat with odorless, consisting of mainly from water, with amino acids, proteins, ammonia, urea, lactic acid and small traces of salts. Apocrine glands secrete sweat that consists of proteins, lipids, and steroids [29]. The expression of human dermcidin (DCD) is localized in skin cells, where is expressed in eccrine sweat glands constitutively, secreted into the sweat and transported to the skin surface [17].

The synthesized Bovine DCD peptide had a broad antimicrobial activity against All microorganisms tested in this study. The most affected species were S. epidermidis, S. bovis and E. faecalis, respectively, which the antimicrobial effect was increased with peptide concentration increased. The highest antimicrobial effect was achieved at 50 and $100 \mu \mathrm{g} / \mathrm{ml}$, where no significant difference between the two concentrations in the effect. S. aureus (MRSA) behaved the same behavior but the maximum antimicrobial effect was achieved at $50 \mu \mathrm{g} / \mathrm{ml}$, and then decreased at $100 \mu \mathrm{g} / \mathrm{ml}$. 
For E. coli the antimicrobial effect was slightly low. In case of C. albicans, it affected with the antimicrobial peptide, where no effect at $1 \mu \mathrm{g} / \mathrm{ml}$ and the inhibitory effects starts at $5 \mu \mathrm{g} / \mathrm{ml}$ increase reaching the maximum at $100 \mu \mathrm{g} / \mathrm{ml}$.

Anionic antimicrobial peptides which are a small group present in ruminants, rich in aspartic and glutamic acids, their general antimicrobial activity Gram-negative and Gram-positive bacteria [10,30]. The fraction of DCD peptide in sweat has antimicrobial spectrum against a wide range of pathogenic microorganisms. Cattle have apocrine sweat glands in which each hair fiber associated with one gland [31,32].

The major dermcidin peptide fragment in sweats is the DCD-1L with 48-mer and has net charge -2 that is anionic and capable of to kill/inhibit microbes like Escherichia coli, Staphylococcus aureus, Staphylococcus epidermidis, rifampin- and isoniazid-resistant Mycobacterium tuberculosis, methicillin-resistant S. aureus, Enterococcus faecalis, Listeria monocytogenes, Salmonella thyphimurium, Pseudomonas putida and Candida albicans [17,25,33,34].

The antimicrobial activity using different $\mathrm{pH}$ values with or without $\mathrm{NaCl}$ concentrations were studied. In all bacterial strains used the varying of $\mathrm{pH}$ value did not affect in the activity of Bovine DCD peptide, except in S. aureus the antibacterial activity affected greatly at pH 4.5 and 5.5 , where the cell death percent is less than $30 \%$. The $\mathrm{NaCl}$ concentrations $100 \mathrm{mM}$ was the optimum which gave the highest antibacterial activity in all bacterial strains except E. coli in which the antibacterial activity was affected greatly after $50 \mathrm{mM} \mathrm{NaCl}$ concentration, where the optimum $\mathrm{NaCl}$ concentration was $50 \mathrm{mM} \mathrm{NaCl}$. The behavior of C. albicans was on contrary to the bacterial behavior, where the antimicrobial activity of Bovine DCD peptide decreased with increasing the $\mathrm{pH}$ in absence and presence of $\mathrm{NaCl}$ concentrations. In general $\mathrm{pH} 6.5$ of the sweat buffer was the most suitable for increasing the activity of the Bovine DCD peptide in all bacterial strains.

Cattle sweat has high contents of total protein nitrogen and the inorganic salt and relatively high urea content [35]. The human DCD-1L has a broad spectrum of antimicrobial activity over a wide $\mathrm{pH}$ range and in high salt concentrations [36]. The antimicrobial activity of DCD-1L is maintained over a broad $\mathrm{pH}$ range and at high salt concentrations that resemble the conditions in human sweat [17].

\section{Conclusions}

The bovine DCD gene expressed in skin cells and the bovine DCD peptide secreted into the sweat which had high antimicrobial activities against Gram-positive and negative bacteria as well as yeast-like fungus. The results revealed that the bovine DCD peptide activity did not affect by different salt concentrations, this means that the bovine DCD peptide was adapted to work in all salt concentrations that secreted in the sweat. 
Supplementary Materials: The following are available online at www.mdpi.com/xxx/s1,
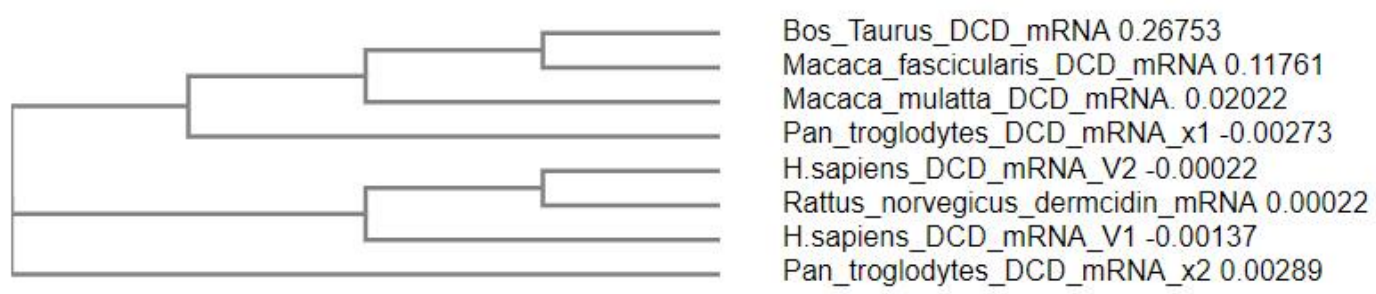

Figure S1. Phylogenetic tree showed the relation between the discovered bovine dermcidin mRNA (this study) and the other dermcidin genes in different organisms.

Skin Spleen Liver Muscle Intestine Kidney Blood

Figure S2. RT-PCR analysis of various tissues. As shown bovine DCD expression was restricted to cells in the skin.

Table S1. Comparative genome map of Chromosome 12 (Homo sapiens), Chromosome 12 (Pan troglodytes), Chromosome 11 (Macaca mulatta) and Chromosome 5 (Bos taurus), the compared segments was mentioned between brackets.

\begin{tabular}{|c|c|c|c|}
\hline \multirow{2}{*}{ Organism } & \multicolumn{2}{|l|}{ Gene } & \multirow{2}{*}{ Locus } \\
\hline & Name & Abbreviation & \\
\hline $\begin{array}{l}\text { Homo sapiens } \\
\text { (Human) }\end{array}$ & Neuronal differentiation 4 & NEUROD4 & $\begin{array}{c}\text { Chromosome 12, NC_000012.12 } \\
(55019945 . .55030017)\end{array}$ \\
\hline $\begin{array}{l}\text { Pan troglodytes } \\
\text { (Chimpanzee) }\end{array}$ & Neuronal differentiation 4 & NEUROD4 & $\begin{array}{c}\text { Chromosome 12, NC_036891.1 } \\
\text { (34055442..34065514, complement) }\end{array}$ \\
\hline $\begin{array}{l}\text { Macaca mulatta } \\
\text { (Monkey) }\end{array}$ & Neuronal differentiation 4 & NEUROD4 & $\begin{array}{c}\text { Chromosome 11, NC_027903.1 } \\
(53721646 . .53731727)\end{array}$ \\
\hline Bos taurus (Cattle) & Neuronal differentiation 4 & NEUROD4 & $\begin{array}{c}\text { Chromosome 5, NC_037332.1 } \\
\text { (59882602..59920743, complement) }\end{array}$ \\
\hline $\begin{array}{l}\text { Homo sapiens } \\
\text { (Human) }\end{array}$ & $\begin{array}{c}\text { Thymocyte expressed, positive } \\
\text { selection associated } 1\end{array}$ & TESPA1 & $\begin{array}{l}\text { Chromosome 12, NC_000012.12 } \\
\text { (54948019..54984746, complement) }\end{array}$ \\
\hline $\begin{array}{l}\text { Pan troglodytes } \\
\text { (Chimpanzee) }\end{array}$ & $\begin{array}{c}\text { Thymocyte expressed, positive } \\
\text { selection associated } 1\end{array}$ & TESPA1 & $\begin{array}{l}\text { Chromosome 12, NC_036891.1 } \\
(34100708 . .34136106)\end{array}$ \\
\hline $\begin{array}{l}\text { Macaca mulatta } \\
\text { (Monkey) }\end{array}$ & $\begin{array}{c}\text { Thymocyte expressed, positive } \\
\text { selection associated } 1\end{array}$ & TESPA1 & $\begin{array}{c}\text { Chromosome 11, NC_027903.1 } \\
\text { (53651281..53686091, complement) }\end{array}$ \\
\hline Bos taurus (Cattle) & $\begin{array}{c}\text { Thymocyte expressed, positive } \\
\text { selection associated } 1\end{array}$ & TESPA1 & $\begin{array}{c}\text { Chromosome 5, NC_037332.1 } \\
\text { (59925012..59960265) }\end{array}$ \\
\hline $\begin{array}{l}\text { Homo sapiens } \\
\text { (Human) }\end{array}$ & Mucin like 1 & MUCL1 & $\begin{array}{c}\text { Chromosome } 12, \text { NC_000012.12 } \\
(54854515 . .54858393)\end{array}$ \\
\hline $\begin{array}{l}\text { Pan troglodytes } \\
\text { (Chimpanzee) }\end{array}$ & Mucin like 1 & MUCL1 & $\begin{array}{c}\text { Chromosome 12, NC_036891.1 } \\
\text { (34226741..34230956, complement) }\end{array}$ \\
\hline $\begin{array}{l}\text { Macaca mulatta } \\
\text { (Monkey) }\end{array}$ & Mucin like 1 & MUCL1 & $\begin{array}{c}\text { Chromosome 11, NC_027903.1 } \\
(53526781 . .53530653)\end{array}$ \\
\hline Bos taurus (Cattle) & Mucin-like 1 & MUCL1 & $\begin{array}{c}\text { Chromosome 5, NC_037332.1 } \\
\text { (25215043..25220249, complement) }\end{array}$ \\
\hline
\end{tabular}




\begin{tabular}{|c|c|c|c|}
\hline $\begin{array}{l}\text { Homo sapiens } \\
\text { (Human) }\end{array}$ & Dermcidin & DCD & $\begin{array}{c}\text { Chromosome 12, NC_000012.12 } \\
\text { (54644591..54648493, complement) }\end{array}$ \\
\hline $\begin{array}{l}\text { Pan troglodytes } \\
\text { (Chimpanzee) }\end{array}$ & Dermcidin & DCD & $\begin{array}{c}\text { Chromosome 12, NC_036891.1 } \\
(34435763 . .34439668)\end{array}$ \\
\hline $\begin{array}{l}\text { Macaca mulatta } \\
\text { (Monkey) }\end{array}$ & Dermcidin & DCD & $\begin{array}{c}\text { Chromosome 11, NC_027903.1 } \\
\text { (53338985..53343039, complement) }\end{array}$ \\
\hline Bos taurus (Cattle) & Dermcidin & DCD & $\begin{array}{c}\text { chromosome 5, NC 037332.1 } \\
(25435277 . .25437603)\end{array}$ \\
\hline $\begin{array}{l}\text { Homo sapiens } \\
\text { (Human) }\end{array}$ & Lacritin & LACRT & $\begin{array}{l}\text { Chromosome 12, NC_000012.12 } \\
\text { (54630839..54634879, complement) }\end{array}$ \\
\hline $\begin{array}{l}\text { Pan troglodytes } \\
\text { (Chimpanzee) }\end{array}$ & Lacritin & LACRT & $\begin{array}{c}\text { Chromosome 12, NC_036891.1 } \\
(34449360 . .34453441)\end{array}$ \\
\hline $\begin{array}{l}\text { Macaca mulatta } \\
\text { (Monkey) }\end{array}$ & Lacritin & LACRT & $\begin{array}{c}\text { Chromosome 11, NC_027903.1 } \\
\text { (53324690..53328815, complement) }\end{array}$ \\
\hline Bos taurus (Cattle) & Lacritin & LACRT & $\begin{array}{l}\text { chromosome } 5, \underline{\mathrm{NC}} 037332.1 \\
(25446731 . .\end{array}$ \\
\hline $\begin{array}{l}\text { Homo sapiens } \\
\text { (Human) }\end{array}$ & $\begin{array}{l}\text { glycosylation dependent cell } \\
\text { adhesion molecule } 1\end{array}$ & GLYCAM1 & $\begin{array}{l}\text { Chromosome 12, NC_000012.12 } \\
\text { (54608187..54610462, complement) }\end{array}$ \\
\hline $\begin{array}{l}\text { Pan troglodytes } \\
\text { (Chimpanzee) }\end{array}$ & 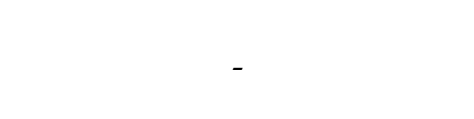 & - & $\cos$ \\
\hline $\begin{array}{l}\text { Macaca mulatta } \\
\text { (Monkey) }\end{array}$ & - & - & - \\
\hline Bos taurus (Cattle) & $\begin{array}{l}\text { glycosylation-dependent cell } \\
\text { adhesion molecule } 1\end{array}$ & GLYCAM1 & $\begin{array}{c}\text { Chromosome 5, NC_037332.1 } \\
(25478966 . .25481870)\end{array}$ \\
\hline $\begin{array}{l}\text { Homo sapiens } \\
\text { (Human) }\end{array}$ & $\begin{array}{l}\text { protein phosphatase } 1 \\
\text { regulatory inhibitor subunit } \\
1 \mathrm{~A}\end{array}$ & PPP1R1A & $\begin{array}{l}\text { Chromosome 12, NC_000012.12 } \\
\text { (54579240..54588659, complement) }\end{array}$ \\
\hline $\begin{array}{l}\text { Pan troglodytes } \\
\text { (Chimpanzee) }\end{array}$ & $\begin{array}{l}\text { protein phosphatase } 1 \\
\text { regulatory inhibitor subunit } \\
1 \mathrm{~A}\end{array}$ & PPP1R1A & $\begin{array}{c}\text { Chromosome 12, NC_036891.1 } \\
(34495553 . .34503977)\end{array}$ \\
\hline $\begin{array}{l}\text { Macaca mulatta } \\
\text { (Monkey) }\end{array}$ & $\begin{array}{l}\text { protein phosphatase } 1 \\
\text { regulatory inhibitor subunit } \\
\text { 1A }\end{array}$ & PPP1R1A & $\begin{array}{c}\text { Chromosome 11, NC_027903.1 } \\
\text { (53271995..53281127, complement) }\end{array}$ \\
\hline Bos taurus (Cattle) & $\begin{array}{l}\text { protein phosphatase } 1 \\
\text { regulatory inhibitor subunit }\end{array}$ & PPP1R1A & $\begin{array}{c}\text { Chromosome 5, NC_037332.1 } \\
(25506930 . .25514982)\end{array}$ \\
\hline $\begin{array}{l}\text { Homo sapiens } \\
\text { (Human) }\end{array}$ & phosphodiesterase 1B & PDE1B & $\begin{array}{c}\text { Chromosome 12, NC_000012.12 } \\
(54549393 . .54579239)\end{array}$ \\
\hline $\begin{array}{l}\text { Pan troglodytes } \\
\text { (Chimpanzee) }\end{array}$ & phosphodiesterase 1B & PDE1B & $\begin{array}{c}\text { Chromosome 12, NC_036891.1 } \\
\text { (34504986..34535264, complement) }\end{array}$ \\
\hline $\begin{array}{l}\text { Macaca mulatta } \\
\text { (Monkey) }\end{array}$ & phosphodiesterase 1B & PDE1B & $\begin{array}{c}\text { Chromosome 11, NC_027903.1 } \\
(53241661 . .53271924)\end{array}$ \\
\hline Bos taurus (Cattle) & phosphodiesterase $1 \mathrm{~B}$ & PDE1B & $\begin{array}{c}\text { Chromosome 5, NC_037332.1 } \\
\text { (25515721..25542387, complement) }\end{array}$ \\
\hline
\end{tabular}


Author Contributions: Conceptualization, N.S. and T.M.; methodology, N.S. and T.M.; formal analysis, N.S. and T.M.; investigation, N.S. and T.M.; resources, N.S. and T.M.; data curation, N.S. and T.M.; writing-original draft preparation, N.S.; writing - review and editing, T.M.

Funding: This research received no external funding.

Conflicts of Interest: The authors declare no conflict of interest.

\section{References}

1. Zasloff, M. Antimicrobial peptides of multicellular organisms. Nature 2002, 415, 389-395.

2. Powers, J.P.S.; Hancock, R.E.W. The relationship between peptide structure and antibacterial activity. Peptides 2003, 24, 1681-1691.

3. Hancock, R.E.; Lehrer, R. Cationic peptides: a new source of antibiotics. Trends Biotechnol. 1998, 16, 82-88.

4. Nicolas, P.; Mor, A. Peptides as weapons against microorganisms in the chemical defense system of vertebrates. Annu. Rev. Microbiol. 1995, 49, 277-304.

5. Janeway, C.A.Jr. Presidential address to the American Association of Immunologists: The road less traveled by: the role of innate immunity in the adaptive immune response. J Immun 1998, 161, 539-544.

6. Hoffmann, J.A.; Kafatos, F.C.; Janeway, C.A.; Ezekowitz, R.A. Phylogenetic perspectives in innate immunity. Science 1999, 284, 1313-1318.

7. Brogden, K.A. Antimicrobial peptides: pore forms or metabolic inhibitors in bacteria? Nat. Rev. Microbiol. 2005, 3, 238-250.

8. Brogden, K.A.; Ackermann, M.; McCray, P.B.Jr.; Tack, B.F. Antimicrobial peptides in animals and their role in host defences. Int. J. Antimicrob. Agents 2003, 22, 465-478.

9. Sheldon, I.M.; Cronin, J.; Goetze, L.; Donofrio, G.; Schuberth, H.J. Defining postpartum uterine disease and the mechanisms of infection and immunity in the female reproductive tract in cattle. Biol. Reprod. 2009, 81, 1025-1032.

10. Brogden, K.A.; Ackermann, M.; Huttner, K.M. Small, anionic, and charge-neutralizing propeptide fragments of zymogens are antimicrobial. Antimicrob. Agents Chemother. 1997, 41, 1615-1617.

11. Luenser, K.; Ludwig, A. Variability and evolution of bovine beta-defensin genes. Genes and Immunity 2005, 6, 115-122.

12. Avellar, M.C.W.; Honda, L.; Hamil, K.G.; Radhakrishnan, Y.; Yenugu, S.; Grossman, G.; Petrusz, P.; French, F.S.; Hall, S.H. Novel aspects of the sperm-associated antigen 11 (SPAG11) gene organization and expression in cattle (Bos taurus). Mol Biol Rep 2007, 76, 1103-1116.

13. Pálffy, R.; Gardlík, R.; Behuliak, M.; Kadasi, L.; Turna, J.; Celec, P. On the physiology and pathophysiology of antimicrobial peptides. Mol. Med. 2009, 15, 51-59.

14. Guani-Guerra, E.; Santos-Mendoza, T.; Lugo-Reyes, S.; Terán, L. Antimicrobial peptides: General overview and clinical implications in human health and disease. Clin. Immun. 2010, 135, 1-11.

15. Dennison, S.R.; Wallace, J.; Harris, F.; Phoenix, D.A. Amphiphilic $\alpha$-helical antimicrobial peptides and their structure/function relationships. Protein and Peptide Lett. 2005, 12, 31-39.

16. Zelezetsky, I.; Tossi, A. Alpha-helical antimicrobial peptides: using a sequence template to guide structure-activity relationship studies. Biochim. Biophys. Acta 2006; 1758, 1436-1449.

17. Schittek, B.; Hipfel, R.; Sauer, B.; Bauer, J.; Kalbacher, H.; Stevanovic, S.; Schirle, M.; Schroeder, K.; Blin, N.; Meier, F.; Rassner, G.; Garbe, C. Dermcidin: a novel human antibiotic peptide secreted by sweat glands. Nat. Immun. 2001, 2, 1133-1137. 
18. Steffen, H.; Rieg, S.; Wiedemann, I.; Kalbacher, H.; Deeg, M.; Sahl, H.G.; Peschel, A.; Götz, F.; Garbe, C.; Schittek, B. Naturally processed dermcidin-derived peptides do not permeabilize bacterial membranes and kill microorganisms irrespective of their charge. Antimicrob. Agents Chemother. 2006, 50, 2608-2620.

19. Li, M.; Rigby, K.; Lai, Y.; Nair, V.; Peschel, A.; Schittek, B.; Otto, M. Staphylococcus aureus mutant screen reveals interaction of the human antimicrobial peptide dermcidin with membrane phospholipids. Antimicrob. Agents Chemother. 2009, 53, 4200-4210.

20. Valore, E.V.; Park, C.H.; Quayle, A.J.; Wiles, K.R.; McCray, P.B.Jr.; Ganz, T. Human beta-defensin-1: An antimicrobial peptide of urogenital tissues. J. Clin. Invest. 1998, 101, 1633-1642.

21. Wintero, A. K.; Fredholm, M.; Andersson, L. Assignment of gene for porcine insulin like growth factor 1 to chromosome 5 by linkage mapping. Anim. Genet. 1994, 25, 37-39.

22. Mömke, S.; Kuiper, H.; Spotter, A.; Drogemuller, C.; Distl, O. A refined radiation hybrid map of the telomeric region of bovine chromosome 18q25-q26 compared with human chromosome 19q13. Anim. Genet. 2005, 36, 141-145.

23. Liu, G.; Zhao, S.; Bailey, J.A.; Sahinalp, S.C.; Alkan, C.; Tuzun, E.; Green, E.D.; Eichler, E.E. Analysis of primate genomic variation reveals a repeat-driven expansion of the human genome. Genome Res. 2003, 13, 358-368.

24. Schutte, B.C.; Mitros, J.P.; Bartlett, J.A.; Walters, J.D.; Jia, H.P.; Welsh, M.J.; Casavant, T.L.; McCray, P.B.Jr. Discovery of five conserved $\beta$-defensin gene clusters using a computational search strategy. PNAS USA 2002, 99, 2129-2133.

25. Cipáková, I.; Gasperík, J.; Hostinová, E. Expression and purification of human antimicrobial peptide, dermcidin, in Escherichia coli. Protein Expr. Purif. 2006, 45, 269-2674.

26. Flad, T.; Bogumil, R.; Tolson, J.; Schittek, B.; Garbe, C.; Deeg, M.; Mueller, C.A.; Kalbacher, H. Detection of dermcidin-derived peptides in sweat by protein chip technology. J. Immunol. Meth. 2002, 270, 53-62.

27. Baechle, D.; Flad, T.; Cansier, A.; Steffen, H.; Schittek, B.; Tolson, J.; Herrmann, T.; Dihazi, H.; Beck, A.; Mueller, G.A.; Mueller, M.; Stevanovic, S.; Garbe, C.; Mueller, C.A.; Kalbacher, H. Cathepsin D is present in human eccrine sweat and involved in the postsecretory processing of the antimicrobial peptide DCD-1L. J. Biol. Chem. 2006, 281, 5406-5415.

28. Rieg, S.; Seeber, S.; Steffen, H.; Humeny, A.; Kalbacher, H.; Stevanovic, S.; Kimura, A.; Garbe, C.; Schittek, B. Generation of multiple stable dermcidin-derived antimicrobial peptides in sweat of different body sites. J Invest Derm 2006, 126, 354-365.

29. Smallegange, R.C.; Verhulst, N.O.; Takken, W. Sweaty skin: an invitation to bite? Trends Parasitol. 2011, 27, 143-148.

30. Brogden, K.A.; De Lucca, A.J.; Bland, J.; Elliott, S. Isolation of an ovine pulmonary surfactant-associated anionic peptide bactericidal for Pasteurella haemolytica. PNAS USA 1996, 93, 412-416.

31. Gebremedhin, K.G.; Wu, B. Sensible and latent heat losses from wet-skin surface and fur layer. ASAE Annual International Meeting; Sacramento, USA; ASABE: USA, 2001; ASAE Paper No. 01-4040.

32. Olson, T.A.; Chase, C.C.Jr.; Lucena, C.; Godoy, E.; Zuniga, A.; Collier, R.J. Effect of hair characteristics on the adaptation of cattle to warm climates. $8^{\text {th }}$ World Congress on Genetics Applied to Livestock Production, Belo Horizonte, Brasil, 2006.

33. Vuong, C.; Voyich, J.M.; Fischer, E.R.; Braughton, K.R.; Whitney, A.R.; DeLeo, F.R.; Otto, M. Polysaccharide intercellular adhesion (PIA) protects Staphylococcus epidermidis against major components of the human innate immune system. Cell Microbiol. 2004, 6, 269-275. 
34. Lai, Y.P.; Peng, Y.F.; Zuo, Y.; Li, J.; Huang, J.; Wang, L.F.; Wu, Z.R. Functional and structural characterization of recombinant dermcidin- 1L, a human antimicrobial peptide. Biochem. Biophys. Res. Commun. 2005, 328, 243-250.

35. Joshi, B.C.; Joshi, H.B.; McDowell, R.E.; Sadhu, D.P. Composition of skin secretions from three Indian breeds of cattle under thermal stress. J Dairy Sci 1968, 51, 917-920.

36. Hong, I.; Kim, Y.S.; Choi, S.G. Simple purification of human antimicrobial peptide dermcidin (MDCD-1L) by intein-mediated expression in E. coli. J. Microbiol. Biotechnol. 2010, 20(2), 350-355. 